\title{
Implementation of the E-Pocket Book to Improve Learning Outcomes in Economics at Madrasah Aliyah Madinatussalam, Bandar Khalifah Regency, Indonesia
}

\author{
Nur Afrianti ${ }^{1}$, Dede Ruslan', Muhammad Yusuf ${ }^{3}$ \\ ${ }^{1}$ Postgraduate Program in Universitas Negeri Medan, Indonesia \\ ${ }^{2,3}$ Universitas Negeri Medan, Indonesia
}

\begin{abstract}
Teaching materials playing a vital role in supporting the learning process in a classroom. The right teaching materials will make the learning process more effective. The problem that is often faced by students is the teaching materials that are not appropriate, so that it lowers student learning outcomes. This causes the low learning outcomes of students in class XI economics MA Madinatusallam. For this reason, researchers try to investigate the effectiveness of epocketbook teaching materials. Field test results showed that the experimental class obtained higher learning outcomes than the control class, with a significant difference $(p=<.05)$.
\end{abstract}

Keywords

teaching materials; epocket book; learning outcomes

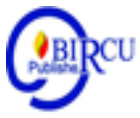

\section{Introduction}

In the learning process, teachers, as people who are considered to have the ability to transfer knowledge to students, are expected to carry out tasks professionally following their disciplines. According to Sugiharto (2020) education is one of the efforts to improve the ability of human intelligence, thus he is able to improve the quality of his life. So, to create the highest quality of human resources, education is becoming an important factor to be considered. The importance of education is also reflected at MPR No. II/MPR/1993 which states that the national education aims to improve the quality of Indonesia people that is religious people, and pious to God Almighty, noble character, has high personality, discipline, work hard, responsible, independent, smart, healthy, physically and mentally healthy.

According to Utomo (2020) education aims to make students happy and make the lives of students better in the future and to achieve happiness in the world and the hereafter based on faith, knowledge, and charity. One of the efforts to improve the quality of education is through improving the teaching and learning process, which contains a series of teacher and student actions on the basis of reciprocal relationships that take place in educational situations to achieve certain goals in the learning process. In realizing these educational goals, the most important thing is how to foster children's personality and diversity. The government has been trying to improve the quality of education by completing the facilities needed by schools to support the learning process (Yusrizal, S. Tanjung and I. Hajar, 2019). However, the facts in the field have not shown satisfactory results, many of the teachers are reluctant to use these facilities for reasons that are complicated in their use. Education in Indonesia is expected to prepare students to become citizens who have a strong and consistent commitment to defending the Unitary State of the Republic of Indonesia (Simanjuntak, 2020). 
Teachers also play a significant role in the development of education, especially those held formally in schools, and have a tremendous influence on the learning process. According to Resien (2020) learning is the process of changing behavior due to interactions among individuals and the environment. Changes in behavior include changes in knowledge, understanding, attitudes, skills, motivation, interests, thinking abilities and so on. Suparman in Sitorus (2019) argues that "learning is a process of behavior change that can be observed by others including by teachers". Dwidayani in Sitorus (2019) states that, "Learning outcomes are measures of success or failure of students after taking teaching and learning activities both in terms of effective, psychomotor, and cognitive which includes knowledge (memory, understanding, application (application)". Learning outcomes are a form of achievement students as well as a symbol of the success of educators in learning students (Yusuf in Sitorus (2019). One of them is the success of student learning. To be successful in their learning, the role of the teacher as a facilitator and motivator is needed. The teacher's task is to convey information to students and be a facilitator in charge of facilitating learning to all students to learn in an atmosphere that is fun, joyful, full of enthusiasm, not anxious, and dares to express opinions openly. A pleasant learning atmosphere can be helped by learning media that can make students enthusiastic in the learning process. Instructional media is a useful auxiliary tool that can be used by teachers to achieve the desired goals. An essential aspect of using media is to help clarify learning messages.

The development of technology, communication and information, especially the internet has become a demand for teachers in Indonesia to be able to use it as a source of positive learning media in supporting teaching and learning processes. The use of technology media provides benefits for teachers and students to access learning materials and interact directly in learning in the classroom, and also outside the classroom through online media (Prasasti, 2019).

According to Sitorus (2020) in general, media users for communicating knowledge and information will provide several benefits to their users, namely the delivery of message content and knowledge to be standard, the learning process clearer and more interesting, the learning process takes place more interactively, the user of time and energy in obtaining information and knowledge becomes more relaxed.

Learning media cannot be separated in the learning process in the classroom to achieve learning objectives. The selection of learning media must be right with the students' conditions in the classroom. If it is not suitable, the teaching and learning process will be more boring. The teacher only uses learning media that is often used in school using textbooks, so that it makes students quickly bored during the learning process. This problem occurs in the MA Madintusalam Bandar Khalifah School, Deli Serdang Regency. Based on the list of values obtained from the class XI Economics learning teacher at MA Madiantusalam, student learning outcomes are still not optimal because many have not reached the KKM (Minimum Completion Criteria). Lack of student interest in the learning process and the learning media used make students experience learning difficulties. Teachers need to create and compile teaching materials that are more effective and right on target to create an enthusiastic learning atmosphere in the classroom. To overcome this problem, an effort is needed to better understand the lesson by using learning media that is very supportive in learning so that student learning outcomes increase in economic learning. 


\section{Review of Literatures}

The process of developing learning products requires good learning planning and design. Teaching materials are essentially messages that want to be conveyed to students to be mastered. Messages are information that will be conveyed in the form of ideas, data/facts, and concepts and so on, which can be in the form of sentences, writings, pictures, maps, or signs. The message conveyed needs to be understood by students, because if it is not understood, the message will not become meaningful information. Some technical considerations in compiling the content or subject matter into teaching materials include (1) conformity with the objectives to be achieved, (2) simplicity, (3) elements of message design, (4) material organization, and (5) instructions. The development of teaching materials must be arranged systematically and must be adjusted to the curriculum, learning tools and the principles of the teaching materials themselves, so that the teaching materials can be used optimally and provide many benefits, among others, students will be interested and grow in interest, to fulfill and master the material which has been given and allows students to learn independently. The characteristics of students with different backgrounds will be very helpful, because they can be studied according to their abilities as well as an evaluation tool for mastery of learning outcomes.

According to Siburian (2020) learning media is things that can channel messages, can stimulate the thoughts, feelings, and wishes of students so as to encourage the creation of learning processes in students themselves. According to the meaning of the media outlined above, then the existence of the media in the learning process is a need that must be met. By using media, students have a uniform perception of the material delivered by the teacher, so there is no difference in information between students in receiving the material given. From the description above it can be concluded that learning media are all things that can be used to channel messages from the sender to the recipient so that they can stimulate the thoughts, feelings, interests and attentions of the participants so that the learning process occurs.

\section{Research Methods}

This research was carried out at the MA Madintusalam Bandar Khalifah School, Deli Serdang Regency in Class XI for the 2020/2021 school year. The time of this research will begin in the Odd Semester of the 2020/2021 academic year. This type of research is experimental development, with data analysis using the Mann-Whitney non-parametric test

\section{Results and Discussion}

\subsection{Results}

a. Homogenity Test

\begin{tabular}{lllllll}
\hline \multicolumn{7}{c}{ Table 1. Test of Homogene ity of Variances } \\
\hline & $\begin{array}{l}\text { Levene } \\
\text { Statistic }\end{array}$ & df1 & df2 & Sig. \\
\hline Pretest & $\begin{array}{l}\text { Based on } \\
\text { Mean }\end{array}$ & 2,723 & 1 & 68 & & 0,104 \\
\hline
\end{tabular}




\begin{tabular}{lllcl}
\hline $\begin{array}{l}\text { Based on } \\
\text { Median }\end{array}$ & 2,934 & 1 & 68 & 0,091 \\
\cline { 3 - 3 } & 2,934 & 1 & 67,230 & 0,091 \\
$\begin{array}{l}\text { Median and } \\
\text { with adjusted } \\
\text { df }\end{array}$ & & & & \\
\hline $\begin{array}{l}\text { Based on } \\
\text { trimmed mean }\end{array}$ & 2,562 & 1 & 68 & 0,114 \\
\hline
\end{tabular}

Based on the table above, it can be concluded that all data are homogeneous. Thus the data can be used to be processed further to the level of hypothesis testing.

\section{b. Normality Test}

The normality test is used to determine whether the sample used is from a normally distributed population or not. The normality test used is the Kolmogorov-Smirnov test calculated with the help of the Spss program. The following is a table of normality test

Table 2. Tests of Normality

\begin{tabular}{llrrrrrr}
\hline \hline & & \multicolumn{3}{c}{ Kolmogorov-Smirnov $^{\mathrm{a}}$} & \multicolumn{4}{c}{ Shapiro-Wilk } \\
\cline { 3 - 9 } Grouping & & Statistic & df & Sig. & Statistic & df & \multicolumn{1}{c}{ Sig. } \\
\hline Learning & Control & 0,269 & 35 & 0,000 & 0,801 & 35 & 0,000 \\
Outcome & Experimental & 0,201 & 35 & 0,001 & 0,893 & 35 & 0,003 \\
\hline \hline
\end{tabular}

a. Lilliefors Significance Correction results.

In testing for normality, the researcher uses the probability parameter ( $\mathrm{Sig}$ ) as a reference, provided that if the probability value is $>0.05$, the data is normally distributed. Meanwhile, if the probability value (Sig) $<0.05$, then the data is not normally distributed. Based on the table, the probability value $<0.05$, the data is not normally distributed, and the data will be further analyzed using non-parametric statistics (Mann-Whitney test).

\section{c. Hypothesis Test}

Hypothesis testing is done using the Mann-Whitney. Following are the results of the Mann Whitney Test table:

Table 3. Mann Whitney Test Results

\section{Test Statistics ${ }^{\text {a }}$}

\begin{tabular}{lr}
\hline \hline & Nilai \\
\hline Mann-Whitney U & 451,000 \\
Wilcoxon W & 1081,000 \\
Z & $-1,956$ \\
Asymp. Sig. (2-tailed) & 0,050 \\
\hline \hline
\end{tabular}

a. Grouping Variable: Class 
Table 4. Descriptive Statistics of the Experimental Class and the Control Class

\begin{tabular}{|c|c|c|c|c|c|}
\hline \multicolumn{4}{|l|}{ Grouping } & \multirow{2}{*}{$\begin{array}{r}\text { Statis tic } \\
81.8571\end{array}$} & Std. Error \\
\hline \multirow{30}{*}{$\begin{array}{l}\text { Learning } \\
\text { Outcomes }\end{array}$} & \multirow[t]{15}{*}{ Control } & \multicolumn{2}{|l|}{ Mean } & & 1.16109 \\
\hline & & $95 \%$ & Lower & 79.4975 & \\
\hline & & Confidence & Bound & & \\
\hline & & Interval for & Upper & 84.2168 & \\
\hline & & Mean & Bound & & \\
\hline & & $5 \%$ Trimmed & Mean & 81.6270 & \\
\hline & & Median & & 80.0000 & \\
\hline & & Variance & & 47.185 & \\
\hline & & Std. Deviatio & & 6.86912 & \\
\hline & & Minimum & & 75.00 & \\
\hline & & Maximum & & 95.00 & \\
\hline & & Range & & 20.00 & \\
\hline & & Interquartile & Range & 15.00 & \\
\hline & & Skewness & & 0.285 & 0.398 \\
\hline & & Kurtosis & & -1.590 & 0.778 \\
\hline & Experimental & Mean & & 84.8571 & 0.75275 \\
\hline & & $95 \%$ & Lower & 83.3274 & \\
\hline & & Confidence & Bound & & \\
\hline & & Interval for & Upper & 86.3869 & \\
\hline & & Mean & Bound & & \\
\hline & & $5 \%$ Trimmed & Mean & 84.8413 & \\
\hline & & Median & & 85.0000 & \\
\hline & & Variance & & 19.832 & \\
\hline & & Std. Deviatio & & 4.45331 & \\
\hline & & Minimum & & 75.00 & \\
\hline & & Maximum & & 95.00 & \\
\hline & & Range & & 20.00 & \\
\hline & & Interquartile & Range & 10.00 & \\
\hline & & Skewness & & 0.058 & 0.398 \\
\hline & & Kurtosis & & -0.439 & 0.778 \\
\hline
\end{tabular}

Based on the Mann Whitney test output table, shown in the table, it is known that $U$ $=541, \mathrm{Z}=-1,956$, and $\mathrm{p}=0.05$. To find out which class has a higher value, look at the two classes' descriptive statistical table. The control class means known to be 81.86 . The experimental class itself has a mean of 84.86. Thus, there are differences in scores between the experimental class and the control class, and this difference is caused by the higher test scores of the experimental class than the control class.

\subsection{Disculssion}

There are differences in learning outcomes in Economics between students who are taught using e-pocket book learning media from the results of research data processing. The Mann Whitney test shows that the coefficient $U=541, Z=-1,956$ and $p=0.05$. To determine which class has the higher learning outcome, look at the two classes' descriptive 
statistical table. The control class mean is known to be 81.86 . The experimental class itself has a mean of 84.86. Thus it can be concluded that there is a difference in scores between the experimental class and the control class, and this difference is caused by the higher test scores of the experimental class than the control class. This result is supported by Saras's (2013) research, which states that the Pocket book is a source of readings consisting of sheets of paper bound with a small size, lightweight, and can be stored in the pocket. Hence, it is easy to carry anywhere and can be read anytime (the pocketbook is a reading source consisting of several sheets of paper with a small size, thin and can be stored in a pocket so that it is easy to carry anywhere and can be read at any time). Moreover, according to Sukarmin and Wahyuningsih (2013), a pocketbook can be interpreted as "a book that is small, light, easy to carry and can be read at any time." The general definition of a pocketbook that contains information and can be stored in a pocket makes it easy to carry anywhere. Through pocketbooks, students can get information without wasting time knowing the essence of the information.

From the above statement, it can be concluded that pocketbooks are small books containing knowledge or information that are easy to carry anywhere, so students will be more diligent in reading than just using textbooks from school. This will make students have a good understanding of the material taught. If students have a good understanding of the learning material, the learning objectives will be easily achieved by increasing student learning outcomes. In line with Alifudin's research (2018), mobile pocketbook media development is declared feasible and can be used as teaching material in schools with a completeness percentage of $83.33 \%$ with a sample of thirty so that it is said to be useful as a student learning medium. Furthermore, it is also supported by research by Apri Widodo (2017) in his research that the digital pocketbook application has succeeded in increasing student learning outcomes in limited tests and operational tests, respectively having a standard gain value of 0.734 and 0.876 .

\section{Conclusion}

\subsection{Conclusion}

Based on the results obtained, it can be concluded that:

a. The e-pocket book is stated to be good in product and suitable for use in class XI MA Madinatusallam for economic learning .

b. The use of e-pocket books is more effective in improving student learning outcomes.

\subsection{Suggestions}

Based on the conclusions that have been described in the conclusions and implications of the research results, the following are some suggestions, namely:

1. It is necessary to hold the readiness of supporting facilities in using interactive learning media, for example, using computers

2. There needs to be training for teachers so that teachers can use a variety of learning media so that it will improve student learning outcomes.

3. To the next researcher, it is hoped that learning e-pocket book learning requires teachers to adjust the content of the material and use of lesson time to affect economic learning outcomes. 


\section{References}

Borg, W. R. Gall, M. D. \& Gall, J. P. (2003). Educational Research: An Introduction. New York: Longman Inc

Khumaidi Alifudin.2018. pengembangan mobile pocket book fisika sebagai media pembelajaan berbasis andorid pada materi momentum dan implus. Vol 07 No 2

Prasasti, T.I., Solin, M., and Hadi, W. (2019). The Effectiveness of Learning Media Folklore Text of North Sumatera Based on Blended Learning by 10th Grade Students of Vocational High SchoolHarapan Mekar-1 Medan. Budapest International Research and Critics in Linguistics and Education (BirLE) Journal Vol 2 (4): 480-490.

Resien, Sitompul, H., and Situmorang, J. (2020). The Effect of Blended Learning Strategy and Creative Thinking of Students on the Results of Learning Information and Communication Technology by Controlling Prior Knowledge. Budapest International Research and Critics in Linguistics and Education (BirLE) Journal Vol 3 (2): 879-893.

Saras Shinta Qurrota'. 2013. Pocketbook As Media Of Learning To Improve Student's Learning Motivation, Jurnal Pendidikan Akuntansi, (online), Vol. XI, No.2

Sulistyani, Nurul Hidayati Dyah. 2013. Perbedaan Hasil Belajar Siswa Antara Menggunakan Media Pocket Book dan Tanpa Pocket Book Pada Materi Kinematika Gerak Melingkar Kelas X, Jurnal Pendidikan.

Simanjuntak, L., Sriadhi, and Saragi, D. (2020). The Effect of Project Based Learning Models and Learning Motivation on Civics Learning Results in 4th Grade Primary School 106163 Percut Sei Tuan. Budapest International Research and Critics in Linguistics and Education (BirLE) Journal Vol 3 (3): 1509-1520.

Siburian, S., Hutagalung, S.M., Daulay, S. (2020). Development of Adobe Flash CS6 Learning Media in Short StoryBased on Learning Text of Advanced Local Community of Batak Toba Students in Tanjungmorawa. Budapest International Research and Critics in Linguistics and Education (BirLE) Journal Vol 3 (1): 591599.

Sitorus, L.S., Mardianto, and Matsum, H. (2020). Development of Powerpoint-Based Learning Media on Learning Aqeedah Morals. Budapest International Research and Critics in Linguistics and Education (BirLE) Journal Vol 3 (2): 958-964.

Sitorus, H. (2019). The Effect of Learning Strategy and Thinking Ability on The Students' Learning Outcomes in Economics Subject of XI Social Students in Senior High School State 1 in Pematang Siantar. Budapest International Research and Critics in Linguistics and Education (BirLE) Journal. p. 451-460.

Sugiharto (2020) Geographical students' learning outcomes on basic political science by using cooperative learning model with Group Investigation (GI) type in State University of Medan, Indonesia, Journal of Human Behavior in the Social Environment, 30:4, 447-456, DOI: 10.1080/10911359.2019.1696261.

Utomo, M.R., Hasruddin, and Murad, A. (2020). Influence of Problem Based Learning Models (PBL) and Learning Motivation to Learn Outcomes and Student's Critical Thinking Skills Themes of Caring for Life in Class IV Primary School No 026609 Pujidadi Binjai. Budapest International Research and Critics in Linguistics and Education (BirLE) Journal Vol 3 (4): 1634-1643.

Widodo April.2017. Pocket Book Learning Media Development Based on Digital Android to Increase Interest and Outcomes Learning of Phyisics Students Grade Sma N 1 Ketis in the Subject Matter Ballance Of Body Right. Jurnal pendidikan fisika vol 6 no 2 tahun 2017. 